\title{
EDITORIAL
}

\section{Refining manuscript elements in the Journal of Neurosurgery: when less is more}

\author{
James T. Rutka, MD, PhD \\ Editor-in-Chief, Journal of Neurosurgery Publishing Group, Charlottesville, Virginia
}

I HAVE long been passionate about the adage "less is more," especially as it refers to medical and scientific writing. A great example is the 1953 scientific article on the discovery of the structure of DNA by James Watson and Francis Crick. ${ }^{1}$ Their seminal report, which helped propel the molecular biology revolution forward, is a mere 128 lines long, with one schematic figure, and fills only two pages of the journal.

With this economy of reporting in mind, the Journal of Neurosurgery Publishing Group (JNSPG) has established limits for the elements of submitted manuscripts. I asked the JNSPG staff to investigate the practices of 15 representative journals-including Stroke, Neurosurgery, New England Journal of Medicine, Journal of Neurology, Neurosurgery and Psychiatry, Lancet, and the Brit- ish Medical Journal-and they found that most of these journals specified limits for text and abstract length (word counts) as well as for numbers of figures, tables, and references. The JNSPG team, with members of the peer review, manuscript editing, production, communications, and policy departments, then calculated descriptive statistics (mean, median, range, standard deviation, 75th percentile, and 90th percentile) from all manuscripts that were edited over a period of 3 months. The team used the raw data and descriptive statistics to develop preliminary recommendations for my review; they then checked the recommendations against a separate 1-month series of accepted manuscripts. Happily, the results showed that the general trend of our current manuscripts is in keeping with the recommendations.

TABLE 1. Manuscript limits

\begin{tabular}{|c|c|c|c|c|c|}
\hline Article Type & Abstract $^{*}$ & Text $^{*}$ & Tables \& Figures $†$ & Videos & References \\
\hline Clinical article & 375 & 4000 & 8 & 2 & 45 \\
\hline Laboratory investigation & 375 & 4000 & 8 & 2 & 45 \\
\hline Literature review (including systematic review) & 375 & 4000 & 8 & 2 & 75 \\
\hline Case report & 200 & 2000 & 5 & 2 & 45 \\
\hline Technical note & 200 & 2500 & 5 & 2 & 45 \\
\hline Historical vignette & 200 & 3500 & 8 & 2 & 45 \\
\hline Opinion & NA & 3500 & 5 & 2 & 45 \\
\hline Letter to the editor or response & NA & 500 & 1 figure or 1 table & video & 10 \\
\hline Neurosurgical Focus & 375 & 3500 & 8 & 2 & 75 \\
\hline \multicolumn{6}{|c|}{$\begin{array}{l}\text { NA = not applicable. } \\
\text { * Total number of words. Text = words from the Introduction through the Conclusions of the manuscript; the Abstract, Acknowledgements, References, } \\
\text { and end matter are not included in the text total. } \\
\dagger \text { Values are totals (tables + figures). JNSPG does not accept tables divided into parts (e.g., Table 1A, Table 1B, etc.); each part will be considered a } \\
\text { separate table, and the manuscript will be returned to the author for renumbering. } \\
\ddagger \text { Applies to all article types except case reports, technical notes, and letters to the editor; use print journal limits for those. }\end{array}$} \\
\hline
\end{tabular}


Our new Manuscript Limits Policy, based on those recommendations, is presented in Table 1; we believe that it will benefit authors in several ways. First, it is highly likely that, by applying these limits to all submissions, we will be able to publish more articles in each issue of our print and online journals. Second, our editorial office will be able to move papers more efficiently through our manuscript submission and article preparation processes. Third, and most importantly, by using economies of language and data presentation (figures, tables, and videos), an author can say more with less-one measure of a truly great writer.

I thank you for working with us as we implement these element limits for submitted manuscripts; we look forward to the positive impact our new policy will have on the neurosurgical literature.

https://thejns.org/doi/abs/10.3171/2017.9.JNS172341

\section{References}

1. Watson JD, Crick FHC: Molecular structure of nucleic acids: a structure for deoxyribose nucleic acid. Nature 171:737738,1953

\section{Disclosures}

The author reports no conflict of interest. 